\title{
Let's Get "Real" about Using Economic Data
}

\author{
Peter Christoffersen, Eric Ghysels, \\ Norman R. Swanson
}

Série Scientifique

Scientific Series

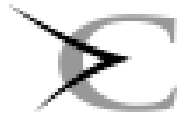

Montréal

Juillet 2001 


\section{CIRANO}

Le CIRANO est un organisme sans but lucratif constitué en vertu de la Loi des compagnies du Québec. Le financement de son infrastructure et de ses activités de recherche provient des cotisations de ses organisationsmembres, d'une subvention d'infrastructure du ministère de la Recherche, de la Science et de la Technologie, de même que des subventions et mandats obtenus par ses équipes de recherche.

CIRANO is a private non-profit organization incorporated under the Québec Companies Act. Its infrastructure and research activities are funded through fees paid by member organizations, an infrastructure grant from the Ministère de la Recherche, de la Science et de la Technologie, and grants and research mandates obtained by its research teams.

\section{Les organisations-partenaires / The Partner Organizations}

-École des Hautes Études Commerciales

-École Polytechnique

-Université Concordia

-Université de Montréal

-Université du Québec à Montréal

-Université Laval

-Université McGill

-Ministère des Finances du Québec

-MRST

-Alcan inc.

-AXA Canada

-Banque du Canada

-Banque Laurentienne du Canada

-Banque Nationale du Canada

-Banque Royale du Canada

-Bell Québec

-Bombardier

-Bourse de Montréal

-Développement des ressources humaines Canada (DRHC)

-Fédération des caisses Desjardins du Québec

-Hydro-Québec

-Industrie Canada

-Pratt \& Whitney Canada Inc.

-Raymond Chabot Grant Thornton

-Ville de Montréal

(C) 2001 Peter Christoffersen, Eric Ghysels et Norman R. Swanson. Tous droits réservés. All rights reserved. Reproduction partielle permise avec citation du document source, incluant la notice $\odot$.

Short sections may be quoted without explicit permission, if full credit, including $\odot$ notice, is given to the source.

Ce document est publié dans l'intention de rendre accessibles les résultats préliminaires de la recherche effectuée au CIRANO, afin de susciter des échanges et des suggestions. Les idées et les opinions émises sont sous l'unique responsabilité des auteurs, et ne représentent pas nécessairement les positions du CIRANO ou de ses partenaires.

This paper presents preliminary research carried out at CIRANO and aims at encouraging discussion and comment. The observations and viewpoints expressed are the sole responsibility of the authors. They do not necessarily represent positions of CIRANO or its partners.

ISSN 1198-8177 


\title{
Let's Get "Real" about Using Economic Data"
}

\author{
Peter Christoffersen ${ }^{\dagger}$, Eric Ghysels ${ }^{\ddagger}$, Norman R. Swanson ${ }^{\S}$
}

\section{Résumé / Abstract}

Nous démontrons que l'utilisation de données qui sont disponibles en temps réel pour établir la sensibilité des prix d'actifs aux nouvelles économiques mène à des résultats empiriques différents de ceux obtenus lorsque la disponibilité des données et les considérations temporelles ne sont pas prises en compte. Pour ce faire, nous nous concentrons sur un exemple en particulier, c'est-à-dire Chen, Roll et Ross (1986), et nous regardons si les innovations aux variables économiques peuvent être perçues comme étant des risques qui sont récompensés dans les marchés des actifs. Nos résultats entérinent la présomption que l'incertitude des données est suffisamment prévalente pour assurer une utilisation prudente des données en temps réel lors de l'établissement de mesures de nouvelles en temps réel, et en général lorsqu'on entreprend des enquêtes financières empiriques impliquant des données macroéconomiques.

We show that using data which are properly available in real time when assessing the sensitivity of asset prices to economic news leads to different empirical findings that when data availability and timing issues are ignored. We do this by focusing on a particular example, namely Chen, Roll and Ross (1986), and examine whether innovations to economic variables can be viewed as risks that are rewarded in asset markets. Our findings support the view that data uncertainty is sufficiently prevalent to warrant careful use of real-time data when forming real-time news measures, and in general when undertaking empirical financial investigations involving macroeconomic data.

Mots Clés : Efficacité des marchés, attentes, nouvelles, processus de révision des données

Keywords: Market efficiency, expectations, news, data revision process

JEL : E17, E44, G11

\footnotetext{
* Corresponding Author: Peter Christoffersen, Faculty of Management, McGill University, 1001 Sherbrooke Street West, Montréal, Qc, Canada H3A 1G5 Tel.: (514) 985-4000 Fax: (514) 985-4039 email: christop@management.mcgill.ca

The authors wish to thank seminar participants at the 1999 Canadian Econometric Study Group and the 2000 World Congress of the Econometric Society for useful comments. Christoffersen thanks FCAR, SSHRC and IFM2, and Swanson thanks the Private Enterprise Research Center at Texas A\&M University for research support, and members of the Department of Economics, University of California San Diego, where parts of this paper were written, for providing a stimulating research environment.

$\dagger$ Mc Gill University and CIRANO

*niversity of North Carolina, Chapel Hill and CIRANO

$\S$ Texas A\&M
} 


\section{Introduction}

There is a long tradition in finance of studying the reaction of markets to macroeconomic news announcements. In principle, asset prices react to news announcements that result in changes in expectations regarding future payoffs and/or discount rates. In practice, it is not surprising to observe financial markets responding to releases of news about industrial production, inflation, labor income, employment, and many other key indicators of the overall health of the economy. Along these lines, many authors have used economic variables as fundamentals in examinations of asset return dynamics (see for instance Chen, Roll and Ross (1986), Fama (1990), Schwert (1990) and Campbell (1996)). Unfortunately, the empirical results to date have been rather disappointing, as the response of stock prices to macroeconomic news has broadly been found to be rather weak. For example, Schwert (1981) finds that the daily response of stock prices to news about inflation is weak and slow. These findings are confirmed by Pearce and Roley (1985) using survey data. In addition, Chen, Roll and Ross (1986) find that covariances between stock returns, industrial production, and other measures of real economic activity are weak. ${ }^{1}$ One argument which is often made when explaining these sorts of findings is that realized variables are too noisy to be used as measures of changes in expectations. In addition, it is not easy to measure "news". One contributing factor to the noise certainly is data revisions. Most macroeconomic data are typically preliminary when they are first released and are subject to many subsequent revisions. In many cases these revisions are substantial and significant, both from a statistical and from an economic point of view. ${ }^{2}$ In addition, extracting news from variables which have been revised many times may not be reasonable, as agents generally extract most news from preliminary or first available data. $^{3}$ Nevertheless, the common approach used in the literature is to use final data. Hence, important informational timing issues which must be dealt with when constructing news variables have largely been ignored.

\footnotetext{
${ }^{1}$ On the other hand, Fama and French (1989) find that the term premium is related to the NBER business cycle, while McQueen and Roley (1993) find evidence of asymmetric market responses to news across business cycles. Taking an interesting tracking portfolio approach, Lamont (1998) finds some significant relationships as well.

${ }^{2}$ In the next section, we review the evidence regarding the magnitude and relevance of revisions of some key macroeconomic conditions variables.

${ }^{3}$ However, it should perhaps be noted that agents also extract news from (early) revisions to economic variables, as has been evidenced in recent years by substantial television coverage of expected and actual updates to various measures of economic activity including GDP and industrial production, for example.
} 
In this paper we address the timing and availability of economic information used in the formation of economic news measures, thereby underscoring the importance of using real-time economic data in financial studies in general. In order to facilitate our introduction of the use of real-time data in the formation of economic news, we follow the approach used by Chen, Roll and Ross (1986), and examine whether innovations to economic variables can be viewed as risks that are rewarded in asset markets.

Chen, Roll and Ross (1986), henceforth CRR, use a regression framework to test whether macroeconomic news measures such as monthly growth in industrial production, annual growth in industrial production, expected inflation and unexpected inflation, and an interest rate spread variable have a systematic influence on stock market returns. Their findings suggest that these "risks" are incorporated in asset prices. As mentioned above, however, other authors have uncovered only weak support for this finding. However, CRR, as well as many related studies which examine the market impact of macroeconomic news, use currently available macroeconomic data. Since revisions to macroeconomic series accrue over time and may be substantial in aggregate, there is potential for serious mismeasurement of macroeconomic news. Moreover, by ignoring the real-time aspects of macroeconomic data, one ignores many interesting issues which hitherto have not been carefully examined in the literature. For example, the potential impact of revisions in economic variables on financial markets is ignored, so that questions of the following sort cannot be answered. Is news constructed using initial releases of economic variables more important than news constructed based on subsequent revisions of initial releases? Does the market care about revised economic activity announcements at all, or do only preliminary announcements matter? We provide at least partial answers to all of these questions by considering both real-time and currently available data in our re-examination of the Chen, Roll and Ross findings. In particular, our approach is to use newly constructed real-time macroeconomic data sets which contain all releases of numerous key monthly and quarterly macroeconomic variables. Thus, we are able to construct data sets which were available in real time. By using real-time data, we are able to shed light on the true real-time impact of macroeconomic news on financial markets. This is done by constructing measures of news that are truly real-time rather than proxies for real-time news that are available only ex-post via the use of subsequently revised economic data. Our main finding is that the incorrect use of final releases of data biases empirical findings concerning the significance of economic news. This in turn suggests that all empirical financial research that involves modeling 
real-time activity should use real-time data. Of course, as financial data such as interest rates and asset prices are not revised, and are hence already real-time, our argument applies only in those cases where macroeconomic measures such as output, inflation, and money growth are used.

The rest of the paper is organized as follows. In the first section we describe the real-time data sets used in our analysis. In addition, we discuss alternative measures of macroeconomic news, and outline the importance of using real-time data when constructing such measures. In Section 2, we outline our implementation of the CRR analysis. Section 3 summarizes our empirical findings, and the final section contains concluding remarks.

\section{Real-Time Economic Data and Measures of Macroeconomic News}

There are several articles and monographs which investigate the size, persistence, predictability and importance of macroeconomic data revisions. For example, an early monograph on the subject of errors in economic data was written by Morgenstern (1963). A number of recent articles in this area (from which many other important references can be obtained) are: Pierce (1981), Ghysels (1982), Mankiw et al. (1984), Maravall and Pierce (1986), Fair and Shiller (1990), Keane and Runkle (1990), Diebold and Rudebusch (1991), Harvey et al. (1993), Kavajecz and Collins (1995), Swanson (1996), and Swanson and White (1997), Swanson, Ghysels and Callan (1999), and Ghysels, Swanson and Callan (2000). Rather than directly dealing with data revision, some papers circumvent the problem by using dummy variables for news announcement dates without actually quantifying the informational content of the news releases (see e.g. Jones, Lamont and Lumsdaine (1998)). Obviously, such an analysis, which focuses only on the announcement event instead of its content, is limited in several ways. A number of other studies which have adopted a variety of related strategies for measuring the impact of news are also not prone to the issues addressed in our paper, but again suffer from similar important limitations. For instance, Mitchell and Mulherin (1994) construct a news index based on the widths of headlines appearing on the front page of the New York Times. While this approach quantifies news coverage, it does not directly measure its reliability and informational content. Note also that revisions to past macroeconomic news releases rarely hit the news wire unless they are substantial.

At this point, it is useful to introduce some notation before proceeding further with our discussion of real-time data. We denote a real-time observation as $y_{t+i}(t)$, which is defined to be the 
$(t+i)^{t h}$ release date of data pertaining to calendar date $t$, where $i>0$. In addition, we classify economic data into three categories: (1) Preliminary, First Released, or Unrevised Data: These types of data consist of the first reported datum for each variable at each calendar date, $t$. The first release of a series is defined as $y_{t+1}(t)$, corresponding to the typical one quarter delay in the release of macroeconomic news (i.e. announcements are of activity in the previous quarter), which is common for quarterly series. (2) Partially Revised or Real-Time Data: These types of data are difficult to collect, as they are made up of vectors of observations, $y_{t+i}(t), i=1, \ldots$, for each calendar date, t. (3) Fully Revised or Final Data: These data are denoted as $y_{f}(t)$. It is quite possible that true final data will never be available for many economic series. This is because benchmark and definitional changes are ongoing and may continue into the indefinite future, for instance. However, in practice we define final data as those revised figures available at some future point in time for calendar date $t$, which are no longer subject to revision. (Of course, and as mentioned above, most financial data are equivalently unrevised and final, as they are not subject to revision.). ${ }^{4}$

In our subsequent analysis, we use two quarterly real-time data sets which were constructed at the Federal Reserve Bank of Philadelphia (see Croushore and Stark (1999)). In particular, we examine real output (GDP) and the implicit price deflator for real output, both for the period 1965:3-1995:3. Data beyond 1995:3 were not used due to a substantial change in the definition of GDP. A detailed discussion of these data sets is given in Croushore and Stark (1999).

We define several processes which will be used in our empirical investigation. For illustrative purposes, these processes are discussed for the case of a generic variables, say $y$. We focus on $k$-step ahead predictions of our variables. When $k=4$, the focus is on today's prediction of next years' real output (this variable is called LRP below), while when $k=1$, the focus is on today's prediction of next quarters' real output (this variable is called SRP below). Unanticipated inflation is formed in the same way, except that the GDP deflator is used instead of GDP. ${ }^{5}$ We try to keep

\footnotetext{
${ }^{4}$ Truly final data are clearly not easy to obtain, as data are generally subject to revision for indefinite lengths of time, as mentioned above. The construction of seasonally adjusted data serves to illustrate this point, as seasonal adjustment filters are of infinite order, at least in principle. See for instance Ghysels and Osborn (2000, Chap. 3) for further discussion.

${ }^{5}$ The formation of these news variables assumes that the conditional expectation of the variables is constant. In addition, we alternatively assume that expectations follow a univariate autoregression (see below for further discussion).
} 
the notation simple, at some cost of incompleteness. ${ }^{6}$ The first release of the $(t+k)^{t h}$ growth rate of real output (say $y$ ) is defined to be:

$$
y_{t, t+k}^{1} \equiv y_{t+k+1}(t+k)-y_{t+k+1}(t) .
$$

This growth rate consists of the difference of the first (log) $y$ figure for quarter $t+k$ released (with one quarter delay) in period $t+k+1$, hence $y_{t+k+1}(t+k)$, and the $k^{t h}$ release of quarter $t$ 's $(\log )$ $y$ figure (i.e. $\left.y_{t+k+1}(t)\right)$. Analogously, any updates of this first released growth rate are denoted as:

$$
y_{t, t+k}^{i} \equiv y_{t+k+i}(t+k)-y_{t+k+i}(t),
$$

for $i=2, \ldots$. The final concurrently available figure is denoted as:

$$
y_{t, t+k}^{f} \equiv y_{f}(t+k)-y_{f}(t)
$$

The following series pertaining to the revision process is useful in our analysis, and can be derived directly from equations (1) through (3):

$$
e_{t, t+k}^{i} \equiv y_{t, t+k}^{f}-y_{t, t+k}^{i}
$$

This series reflects the (revision) error in the growth rate, relative to the final data sample point which is concurrently available. When $i=1$, this error represents the difference between the preliminary announcement of the $k$-step growth rate, and its final revised value. ${ }^{7}$

Before turning to our discussion of the CRR model, it is perhaps worth discussing some of the salient features of our real-time data sets. Summary statistic and graphs are given in Table 1 and Figures 1 and 2. For ease of comparison, all reported data are annualized percentages. In Figure 1, the top 2 panels contain plots of preliminary real GDP releases (the right panel is $y_{t, t+1}^{1}$ (annualized) and the left panel is $\left.y_{t, t+4}^{1}\right)$. These data are representative of the magnitude of annualized quarteron-quarter and year-on-year output growth, as estimated by the reporting agencies immediately after the close of the calendar quarter to which the data pertain. These data can be compared, for example, with final figures, which are plotted in the bottom 2 panels of Figure 1. Interestingly,

\footnotetext{
${ }^{6}$ See Swanson, Ghysels and Callan (1999) a detailed discussion of notation which is useful when characterizing real-time series.

${ }^{7}$ Another error process which will be of interest is the revision error across different vintages, namely: $e 1_{t, t+k}^{i} \equiv$ $y_{t, t+k}^{i}-y_{t, t+k}^{1}$.
} 
while annualized growth rates appear smoother after final revision, quarterly growth rates (see the right lower panel) appear more variable. The extent revision to the data as we move from preliminary to final figures is portrayed in the center two plots in Figure 1, where $e_{t, t+1}^{1}$ and $e_{t, t+4}^{1}$ are graphed for the period 1965:3-1995:3. Two important observations based on these plots of the revision process are the following. First, the revision process for quarter-on-quarter growth is indeed highly variable relative to that for year-on-year growth. Second, the magnitude of revisions is very large relative to the magnitudes of either the raw preliminary or the raw final data. For example, the revision to the annualized quarterly growth rate for 1975:1 is around 5\%, while no single raw output growth rate for any quarter is greater than $11 \%$ in absolute magnitude. However, casual inspection of the revision process plots suggests that the mean revision is close to zero. Thus, while revisions play an important role in the characterization of data, preliminary output figures are not necessarily biased estimates of final figures. This characteristic of the data is explored further in Table 1, which contains various summary measures of the output and deflator data sets. The upper panel of the table contains summary statistics for the raw series, which are included in order to help the reader assess the extent of data revision relative to the absolute magnitude of the series. The lower panel contains statistics calculated using various revision series. Notice that summary statistics for $e_{t, t+1}^{1}$ and $e_{t, t+4}^{1}$, corresponding to those revision processes plotted in the center panels in Figure 2, are given in the first and fourth row of the second panel in Table 1 for output, for example. Consider $e_{t, t+1}^{1}$. The mean revision of this series is 0.25 , and the $p$-value associated with a test of the null hypothesis that there is no preliminary release bias is 0.12 , which implies rejection of the null at an $88 \%$ level of confidence. Thus, although the evidence is moderate, we can say that preliminary output growth rate estimates are biased. The sixth row of the second panel of Table 1 summarizes the revision process from first to second release for year-on-year output growth, and in this case the mean revision error of 0.06 is significantly different from zero at a $96 \%$ level of confidence, suggesting that while the revision from first to second release is small in magnitude, it varies little from its average value of $0.06 \%$. Summary statistics for the deflator are also given, and it is clear that there is generally substantial and significant bias in preliminary and second release data (i.e. see means in the rows with vintages denoted $e_{t, t+1}^{1}, e_{t, t+1}^{2}, e_{t, t+4}^{1}$, and $e_{t, t+4}^{2}$ ). This finding is not obvious if one looks only at the plots of the revision process in Figure 1. Another interesting feature of the revision processes summarized in the table is that the Jarque-Bera test of normality always suggests rejection of the null that the data are normally distributed. One of the reasons for 
this is that the raw series and the revision series are usually characterized by kurtosis in excess of 3 , which suggests that the distributions of the series are leptokurtotic (peaked relative to the normal). Finally, note that the last column of the table contains $p$-values for Ljung-Box autocorrelation tests with 1, 5, and 10 lags. Rejection of the null hypothesis in this case (which occurs frequently for our revision series based on a 0.10 significance level) suggests that there is a stochastic component of the revision series which is not white noise, and which can be modeled, thereby extracting information about future revisions from current and past revisions. All of these findings suggest that ignoring the timing and availability of macroeconomic data by using only currently available data may lead to spurious conclusions when carrying out real-time analyses such as assessments of the impact of news on the stock market and real-time decision making behavior. In the next section we turn to a discussion of our empirical investigation of the significance of macroeconomic news.

\section{The Risk Premia of Real-Time Macro Variables}

We begin our discussion by proceeding along the lines of Chen, Roll and Ross (1986). As mentioned above, CRR aim to test whether macro risks, measured by innovations to macroeconomic variables are rewarded in the stock market. They use a framework which broadly follows that of Fama and McBeth (1973). Along these lines, they view a stock price as the expectation of discounted dividends, and form a set of variables which theory suggests should systematically affect stock market returns. The variables include:

- unanticipated short (SRP) and long run (LRP) changes in output measured by next month's growth rate, and next year's growth rate in industrial production (IP)

- the change in anticipated inflation, constructed using the expected real rate of interest as in Fama and Gibbons (1984)

- unanticipated inflation (UI)

- unanticipated changes in the credit risk premium measured by the excess return of low grade bonds over long government bonds (URP) 
- unanticipated changes in the term structure, measured by the excess return on long government bonds over T-bills $(U T S)^{8}$

In order to reduce the noise in individual equity returns, CRR use returns on 20 size-sorted, equal-weighted equity portfolios as opposed to individual equity returns. We follow their example and use the 25 size-sorted and book-to-market sorted portfolio returns from Kenneth French's data library. ${ }^{9}$ In addition, our analysis is based on quarterly data because monthly IP data is known to be very noisy, because quarterly GDP data is more comprehensive than IP data, and because we have a high-quality real-time data set available at the quarterly frequency from Croushore and Stark (1999). However, switching to quarterly GDP data renders CRR's assumption of output growth rates being white noise less attractive. Thus, we estimate simple proxies for output and inflation expectations. Further, as anticipated changes in inflation and anticipated changes in the term structure are virtually never significant in CRR's analysis, we do not include them here. ${ }^{10}$

We follow the CRR procedure for estimating the risk premia on macro news by conducting a multivariate version of the Fama and McBeth (1973) approach. First, for each year in the dataset, we estimate time-series regressions of each stock return on the macro news variables to obtain the (time-varying) risk factors $\left(\beta^{\prime} s\right)$. CRR use 60 months of past data in each annual regression, we use 60 quarters. Thus, for each stock return, $i$, we estimate:

$$
R_{i}=\alpha_{\tau}^{i}+\beta_{\tau, L R P}^{i} L R P+\beta_{\tau, S R P}^{i} S R P+\beta_{\tau, U I}^{i} U I+\beta_{\tau, U P R}^{i} U P R+\varepsilon^{i}
$$

where $\tau$ denotes the final year in each subsample, and where each variable is a vector of quarterly time-series observations from year $\tau-14$ through year $\tau$. Second, at the end of each year in the data set, we estimate quarterly cross-sectional regressions of stock returns on the betas for the next four quarters, from which we obtain a time series of risk-premia $\left(\gamma^{\prime} s\right)$. For each quarter, $j=1,2,3,4$, in the year following year $\tau$, we estimate the $\gamma$ 's in:

$$
R_{\tau+j}=\alpha_{\tau+j}+\gamma_{\tau+j, L R P} \beta_{\tau, L R P}+\gamma_{\tau+j, S R P} \beta_{\tau, S R P}+\gamma_{\tau+j, U I} \beta_{\tau, U I}+\gamma_{\tau+j, U P R} \beta_{\tau, U P R}+\varepsilon_{\tau+j}
$$

\footnotetext{
${ }^{8}$ They also examine other market risks, including oil price risk. However, as they do not find these risks to be significant, and given that we do not have real-time data available for these other risks, we focus our attention only on those listed above.

${ }^{9}$ http://web.mit.edu/kfrench/www/data_library.html

${ }^{10}$ However, we do use anticipated changes in order to calcuate unanticipated changes.
} 
where each variable is a vector of cross-sectional observations over the 25 equity portfolios. Third, from the time-series of risk premia, we calculate the averages over time and standard errors and t-statistics, using:

$$
t\left(\bar{\gamma}_{y}\right)=\sqrt{T} \bar{\gamma}_{y} / \sigma\left(\gamma_{t, y}\right), \quad y=L R P, S R P, U I, U P R
$$

where $\bar{\gamma}_{y}$, and $\sigma\left(\gamma_{t, y}\right)$ are the time-series mean and standard deviation of $\gamma_{t, y}$, respectively, and where $T$ is the number of quarters in the entire sample after the initial estimation subsample.

While the $U P R$ variable is a financial time series which is not subject to revision, the variables, $L R P, S R P$, and $U I$ are based on real output and the GDP deflator, and are frequently and often substantially revised, as we saw in Figures 1 and 2. It is therefore of interest to run two versions of the CRR analysis: one based on the standard final release data; and one based on real-time data. We also report a third version of the analysis where final-release growth rates are used to measure raw innovations, but where the expectations of the raw innovations are calculated using real-time data. In addition, we carry out two parallel analyses which differ with respect to the assumption about the expectations of the economic variables. In the first version, all economic variables are assumed to have conditional expectations equal to their unconditional expectations. This corresponds to CRR. In the second version, each variable is assumed to have expectations that follow a univariate autoregression which takes into account reporting lags in the variables.

\section{$3 \quad$ Empirical Findings}

The results of the quarterly CRR analysis using the different assumptions about expectations are reported in Tables 2 and 3. In Table 2, we report the CRR regressions using raw innovations in the economic variables. Thus, the conditional mean for each variable is simply assumed to be constant over time. Table 3 contains results based on the assumption that expectations follows a univariate autoregression. Panel A in Table 2 shows the average risk premia when the CRR regressions are run on final-release data, which is of course the convention in the literature, while Panels B report similar statistics, but based on the use of real-time data. In Table 3, there is an additional panel, namely Panel $\mathrm{C}$, in which real-time data are modelled using real-time expectations (see the above discussion). Before turning to a detailed discussion of our empirical findings, it is worth stressing that we consider three different specifications with respect to the output variable. First, the four-quarter lead of the annual growth rate in real GDP is used. Second, the one-quarter 
ahead, quarterly growth rate in real GDP is used, and finally, both output variables are included. CRR initially use the latter specification in their analysis, but quickly drop the annual growth variable, as it is insignificant in their analysis.

Two clear findings emerge upon examination of Table 2. Notice first that regardless of output specification, when using final-release data, real output risk is never significantly priced. Put another way, note that while the sign of the output risk premium is everywhere positive, meaning that output risk is rewarded, it is not statistically significant. On the other hand, the premium on inflation risk is significantly negative across output specifications, which matches CRR's finding, and which can be interpreted as stocks being hedges against the inflation risk of other (fixed income) assets. Further, and as expected, the credit premia are positive and significant across all output specifications. Second, with regard to reward significance based on the use of real-time data to define risks (see Panel B), note that real output is now statistically significant in most cases. Thus, real-time output risk is more robustly priced than final-release output risk. Thus, the rewards from output risk are more precisely estimated when using real-time data than when using final-release data. Inflation risk is still negative and significant across all specifications.

As alluded to above, one assumption underlying Table 2 is that the conditional expectation is constant through time for all variables, so that no instrumenting for expectations is necessary. We now dispose of this assumption and assume that all variables follow simple autoregressive processes. As the output variables are in one and four period leads, respectively, we don't regress on the immediately preceding observation, but rather on the observation known at time $t$. We also take into account the fact that quarterly NIPA data are reported with a one-quarter lag. Finally, we run three different versions of our three output models. First, we instrument for final release data using final release instruments (Panel A). Notice that, while this is standard practice, it is NOT a realistic experiment. Final release data are subject to many revisions after their initial release and should therefore not be used in a proper time- $t$ information set. We include this case simply because it is standard practice, and because we want to illustrate that the standard approach can be misleading. Second, we instrument for final release data using real-time instruments which are available at time $t$. Finally, we instrument for real-time data using real-time instruments.

Turning now to the results in Table 3, note first (Panel A) that when the surprise in final release data is calculated using final-release instruments, output is again insignificant and much smaller than before. In fact, as opposed to Panel A of Table 2, only the negative premium on 
inflation risk is still significant. Keeping in mind again, that instrumenting using final-release data is not possible in real-time, in Panel B we redo the experiment in Panel A, but using realtime instruments for the final release data. Notice now that essentially nothing is significant anymore. This suggests that if we relax the constant conditional expectations assumption of CRR and we additionally use only real-time data, then the rewards from inflation and output risk are not significant when using real-time data, as opposed to the case when final data are used and conditional expectations are assumed fixed. Thus, we have evidence that not only are real-time data crucial, but realistic expectations assumptions also play a role - both issues, when correctly dealt with, lead to qualitatively and quantitatively different findings relative to the case when incorrect data and/or expectational assumptions are employed. Finally note that although we instrument for final data using real-time data in Panel B, another valid real-time approach is to instrument for real-time data using real-time data. ${ }^{11}$ Now, the result from Table 2 that two out of three inflation risk premia are negative and significant again holds. However, we remain with the new finding that output risk premia are positive, but are not significant. Although our real-time findings (in Panels B and C) do change slightly depending on which data are instrumented for in Table 3, the above finding remains. In particular, we see that the significance of risk rewards is dependent upon which type of data are used. In addition, it is worth stressing that one argument for viewing the results from Panel B as being the "correct" real-time results is the following. Assuming that agents respond not only to preliminary data announcements, but also to later data updates suggests that we should use data available in real-time to instrument for final release data rather than preliminary data. In this sense, the results in Panel C should be viewed with caution, and are only included for completeness. Finally, all of the above experiments were also carried out using vector autoregressive instead of univariate autoregressive processes to proxy for expectations. Results were qualitatively similar to those found based on univariate expectations formation, however, and are not reported.

To summarize, Tables 2 and 3 illustrate several aspects of the importance of using real-time data in financial economics. Using final-release data, when the use of real-time data is appropriate can

\footnotetext{
${ }^{11}$ The debate concerning whether to use final data or real-time data when forming news measures and comparing predictions from alternative models remains open. For this reason, we include results from both of these valid realtime approaches. In the current context, the choice between the two approaches ultimately boils down to which assumption one is willing to make with regard to which variable (either preliminary or final) agents are trying to predict.
} 
essentially mislead inference in one of two possible ways: First, results which are insignificant using final-release data can easily be significant when using real-time data. Second, the opposite case may arise. In particular, results which are significant using final-release data could be insignificant when using real-time data. Both problems are of course important. In the above analysis we found examples of both. In Table 2, we found that when assuming expectations are constant over time, output risk is more precisely estimated using real-time data than when using final-release data. Thus, relying on final-release data alone would lead the researcher to conclude that output risk is not significantly priced. However, when forming expectations using what is arguably a more realistic approach (see Table 3), the premium on inflation risk is significantly negative and large in magnitude when expectations are instrumented for using final-release data (Panel A) which actually were not available at time $t$, whereas when correctly instrumenting for final data in real time (Panel B), the inflation risk premium is small and insignificant. Finally, note that the results in Panel B of Table 3 represents what we view as our "most" realistic setup in terms of expectation formation. In addition, these results use our preferred approach of instrumenting for final data using real-time data (an approach which is valid from the perspective of data availability). This suggests that the results reported in Panel B of Table 3 summarize our "ultimate" findings concerning the significance of risk rewards. In particular, no macroeconomic risks are found to be significant, so that we have evidence that macroeconomic risk is not rewarded in the stock market. Of course, it should be understood that our findings are limited in the sense that many other macroeconomic risks could and perhaps should be examined. We do not do this here, however, as we instead focus on the importance of using valid, real-time data in empirical finance applications.

\section{Concluding Remarks}

The idea of assessing whether macroeconomic variables can be viewed as risks that may be rewarded in the stock market is an elegant one. Risk measures are designed to reflect market expectations, and therefore reveal the impact of news. However, the construction of these measures has largely been based on the use of macroeconomic data which are not only subject to revision, but have been revised many times. In this paper we have examined the impact, within the framework of Chen, Roll and Ross (1986) of properly using real-time data sets that were truly available at the time that economic expectations were formed. Our primary conclusion is that real-time data should 
be used in the construction of news measures, and more generally that real-time macroeconomic data should not be overlooked when carrying out a variety of empirical analyses for which the timing and availability of macroeconomic information may matter. This conclusion is supported by evidence suggesting that the significance of the rewards to macro risks are impacted when realtime as opposed to final data are used in experiments using the framework of Chen, Roll and Ross (1986). 


\section{References}

[1] Campbell, John Y. (1996) Understanding Risk and Return, Journal of Political Economy, 104, 267-297.

[2] Chen, Nai-Fu, Richard Roll and Stephen A. Ross, (1986), Economic Forces and the Stock Market, Journal of Business 59, 383-403.

[3] Croushore, Dean and Tom Stark (1999), A Real-Time Dataset for Macroeconomists, Working Paper No. 99-4, Federal Reserve Bank of Philadelphia.

[4] Diebold, Francis X. and Glenn D. Rudebusch (1991), Forecasting Output with the Composite Leading Index: A Real Time Analysis, Journal of the American Statistical Association, 86, 603-610.

[5] Fair, Ray and Robert Shiller (1990), Comparing Information in Forecasts from Econometric Models, American Economic Review, 80, 375-389.

[6] Fama, Eugene F. (1990), Stock Returns, Expected Returns and Real Activity, Journal of Finance 45, 1089-1108.

[7] Fama, Eugene F. and Kenneth R. French (1989), Business Conditions and Expected Returns on Stocks and Bonds, Journal of Financial Economics, 25, 23-49.

[8] Fama, Eugene F., and Michael Gibbons (1984), A comparison of Inflation Forecasts, Journal of Monetary Economics, 13, 327-48.

[9] Fama, Eugene F., and James D. McBeth (1973), Risk, Return, and Equilibrium: Empirical Tests, Journal of Political Economy, 38, 607-36.

[10] Ghysels, Eric (1982), Tydreeksanalyse en fouten in BNP-cyfers een theoretische korrektie en herinterpretatie, Cahiers Economiques de Bruxelles, 96, 489-95.

[11] Ghysels, Eric and Denise R. Osborn (2000), The Econometric Analysis of Seasonal Time Series, Cambridge University Press.

[12] Ghysels, Eric, Norman R. Swanson and Myles Callan (2000), Monetary Policy with Model and Data Uncertainty, Working Paper, Texas A\&M University. 
[13] Harvey, Andrew C., C.R. McKenzie, D.P.C. Blake and M.J. Desai (1993), Irregular Data Revisions in A. Zellner (ed.), Applied Time Series Analysis of Economic Data, Bureau of the Census, 329-347.

[14] Jones, Charles M., Owen Lamont, and Robin L. Lumsdaine (1998), Macroeconomic News and Bond Market Volatility, Journal of Financial Economics, 47, 315-337.

[15] Kavajecz, K.A. and S. Collins (1995), Rationality of Preliminary Money Estimates, Review of Economic Studies, 62, 32-41.

[16] Keane, Michael P. and David E. Runkle (1990), Testing the Rationality of Price Forecasts, American Economic Review, 80, 714-35.

[17] Lamont, Owen (1998), Economic Tracking Portfolios, Manuscript, Graduate School of Business, University of Chicago. Forthcoming in the Journal of Econometrics.

[18] Mankiw, N. Gregory, David E. Runkle, and Matthew D. Shapiro (1984), Are Preliminary Announcements of the Money Stock Rational Forecasts? Journal of Monetary Economics, 14, $15-27$.

[19] Maravall, Augustin and David Pierce (1986), The Transmission of Data Noise Into Policy Noise in U.S. Monetary Control, Econometrica, 54, 961-979.

[20] McQueen, Grant and V. Vance Roley (1993), Stock Prices, News, and Business Conditions, Review of Financial Studies, 6, 683-707.

[21] Mitchell, Mark and Harold Mulherin (1994), The Impact of Public Information on the Stock Market, Journal of Finance, 49, 923-950.

[22] Morgenstern, O. (1963), On the Accuracy of Economic Observations, 2nd Ed., Princeton University Press, Princeton.

[23] Pearce. D.K. and V.V. Roley (1985), Stock Prices and Economic News, Journal of Business, $58,49-67$.

[24] Pierce, D.A. (1981), Sources of Error in Economic Time Series, Journal of Econometrics, 17, 305-321. Investment Accelerator, Journal of Political Economy, 97, 251-287. 
[25] Schwert, G.W. (1981), The Adjustment of Stock Prices to Information about Inflation, Journal of Finance, 36, 15-29.

[26] Schwert, G.W. (1990), Stock Returns and Real Activity: A Century of Evidence, Journal of Finance, 45, 1237-1257.

[27] Swanson, N.R. (1996), Forecasting Using First-Available Versus Fully Revised Economic TimeSeries Data, Studies in Nonlinear Dynamics and Econometrics, 1, 47-64.

[28] Swanson, N.R., E. Ghysels and M. Callan (1999), A Multivariate Time Series Analysis of the Data Revision Process for Industrial Production and the Composite Leading Indicator, in Engle, R.F. and H. White (ed.) Festschrift in Honor of Clive W.J. Granger, Oxford University Press, 45-75.

[29] Swanson, N.R. and H. White (1997), A Model Selection Approach to Real-Time Macroeconomic Forecasting Using Linear Models and Artificial Neural Networks, Review of Economics and Statistics, 79, 540-550. 
Four-Quarter Growth: Real-Time
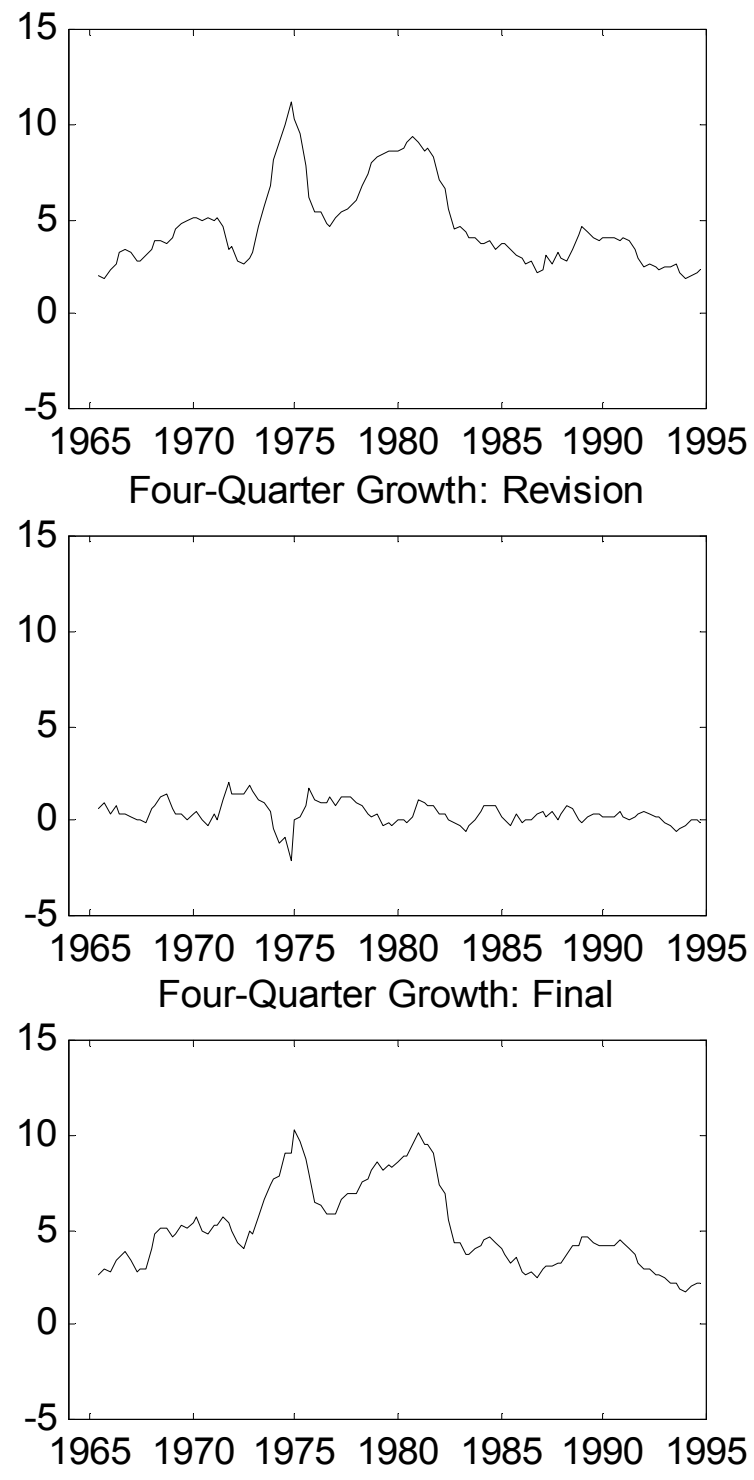

One-Quarter Growth: Real-Time
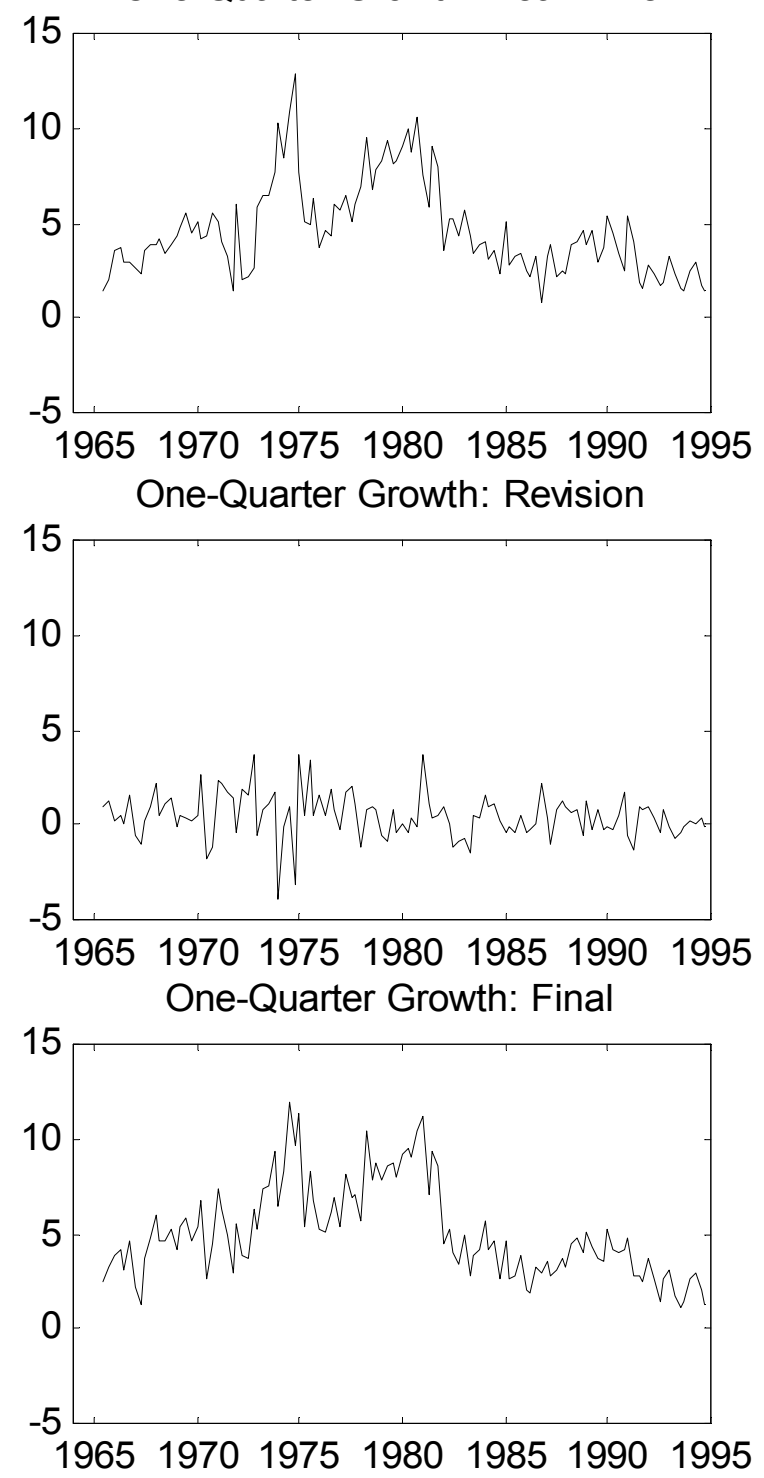

Figure 1. GDP Deflator. The top panels show the four-quarter and one-quarter growth rates in the first-release of the GDP deflator. The middle panels show the difference between the final release and the first release of the four-quarter and one-quarter growth rates. The bottom two panels show the final releases. All growth rates are constructed using the differences in the logs of the series. The one-quarter growth rates are annualized by multiplying by four. 
Four-Quarter Growth: Real-Time
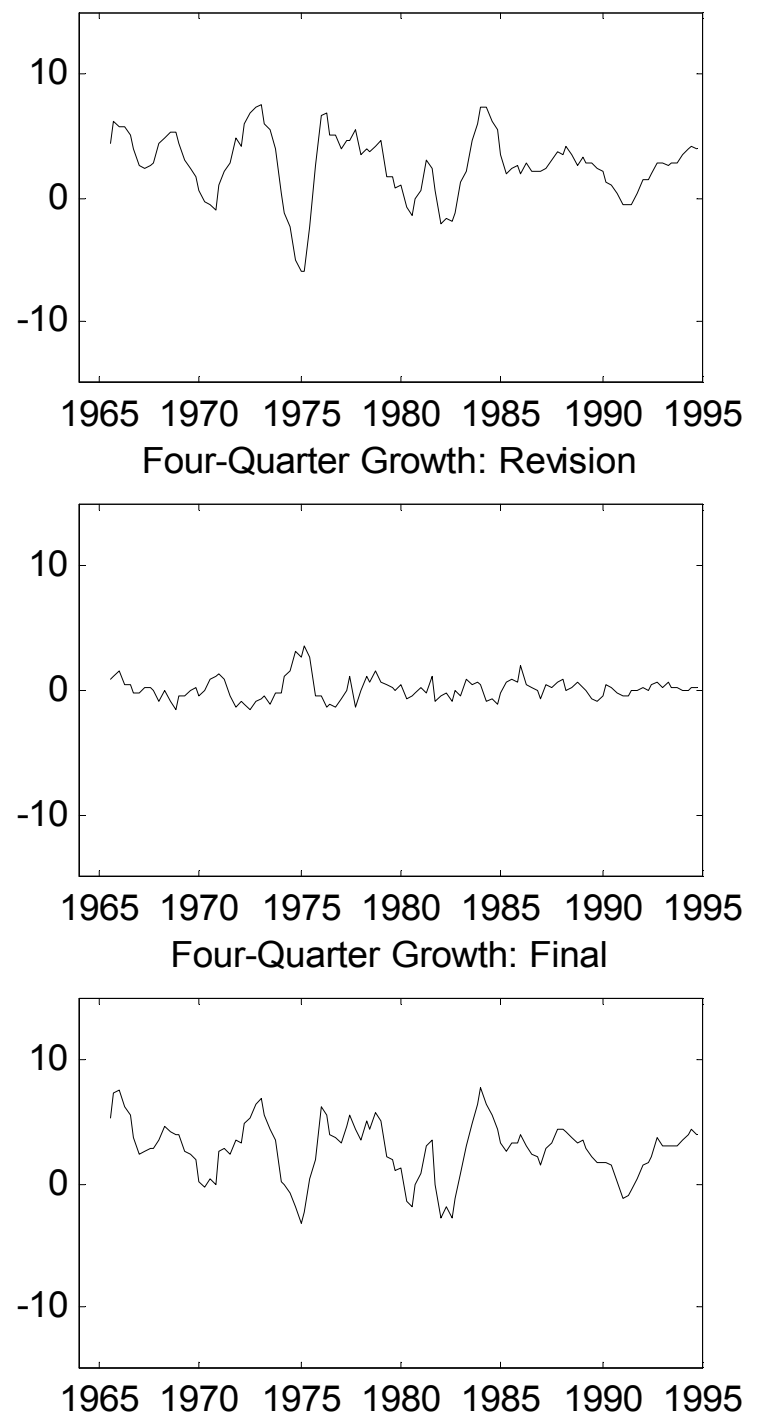

One-Quarter Growth: Real-Time
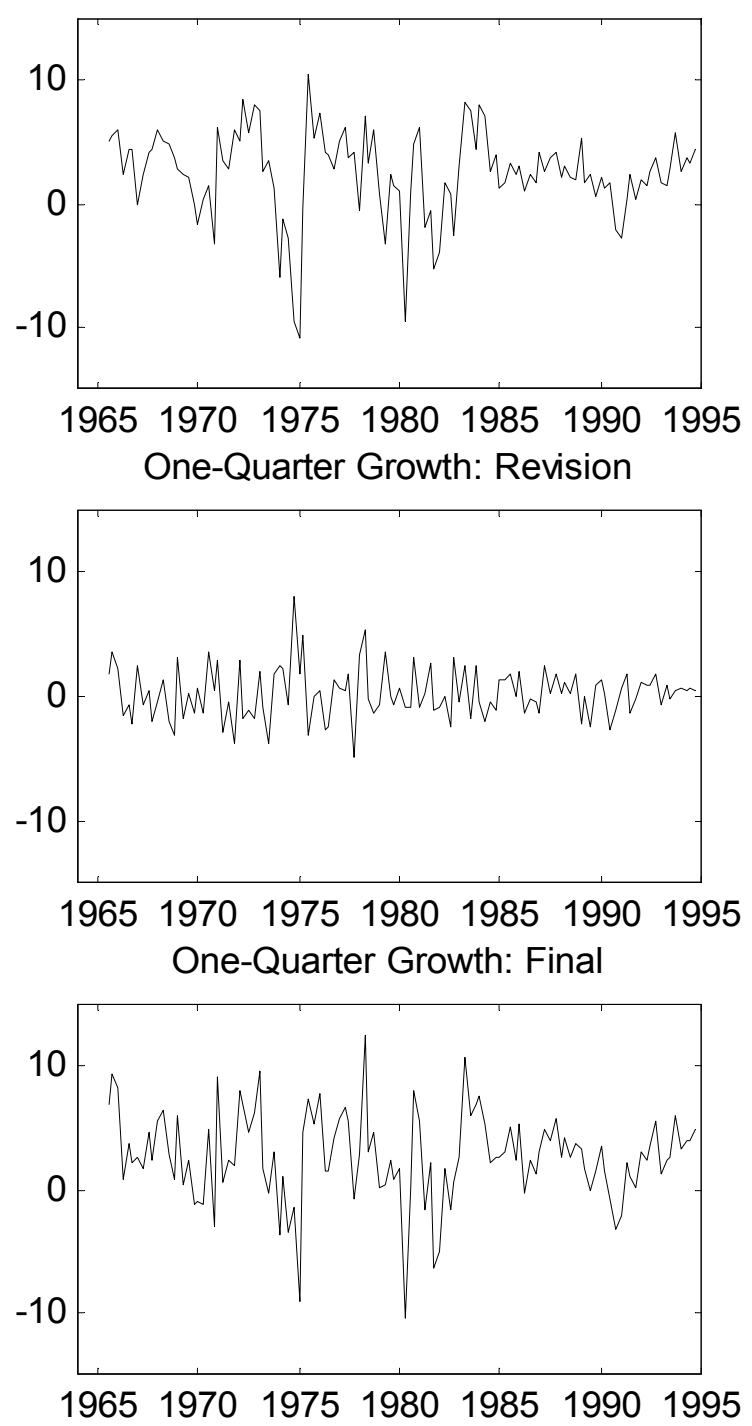

Figure 2. Real Output. The top panels show the four-quarter and one-quarter growth rates in the first-release of real output. The middle panels show the difference between the final release and the first release of the four-quarter and one-quarter growth rates. The bottom two panels show the final releases. All growth rates are constructed using the differences in the logs of the series. The one-quarter growth rates are annualized by multiplying by four. 


\section{Table 1: Quarterly Real-Time Data Set Summary Statistics}

In the first panel of the table, we consider first, second and final vintages of quarterly and annual growth rates of the Real Output and the GDP Deflator variables. The revision series, which are summarized in the second panel of the table are: final revised minus first available $\left(e_{t, t+i}^{l}\right)$, final revised minus second available $\left(e_{t, t+i}^{2}\right)$, and second available minus first available $\left(e 1_{t, t+i}^{2}\right)$. All growth rates summarized in the table are expressed as annualized percentages. Bracketed values beside the means of the series are $p$-values associated with a test of the null hypothesis that there is significant bias in the revision process. The $p$ values are constructed using heteroskedasticity and autocorrelation consistent standard error estimates. In addition, $p$-values associated with the Jarque-Bera normality test and Ljung-Box autocorrelation tests ( $p$ values given for lags 1,5 and 10) are reported in the 8th and 9th columns of the table. Ljung-Box $p$-values are not reported for the raw series, as they are always 0.00. Data are for the period 1965:3 - 1995:3.

\section{Raw Series}

\begin{tabular}{|c|c|c|c|c|c|c|c|c|}
\hline Series & Vintage & Growth Rate & Mean & $\underline{\text { Strd Err }}$ & Skewness & Kurtosis & Jarq.-Bera & Q Stats \\
\hline \multirow[t]{6}{*}{ Real Output } & $1 \mathrm{st}$ & Quarter & 2.45 & 3.53 & -1.11 & 5.55 & 0.00 & - \\
\hline & 2nd & & 2.64 & 3.79 & -1.01 & 5.57 & 0.00 & - \\
\hline & final & & 2.71 & 3.60 & -0.51 & 4.68 & 0.00 & - \\
\hline & $1 \mathrm{st}$ & Year & 2.62 & 2.65 & -0.72 & 3.92 & 0.00 & - \\
\hline & 2nd & & 2.69 & 2.67 & -0.68 & 3.80 & 0.00 & - \\
\hline & final & & 2.74 & 2.35 & -0.42 & 2.89 & 0.17 & - \\
\hline GDP & $1 \mathrm{st}$ & Quarter & 4.54 & 2.44 & 0.96 & 3.54 & 0.00 & - \\
\hline \multirow[t]{5}{*}{ Deflator } & 2nd & & 4.67 & 2.56 & 1.05 & 3.67 & 0.00 & - \\
\hline & final & & 4.99 & 2.50 & 0.70 & 2.87 & 0.00 & - \\
\hline & $1 \mathrm{st}$ & Year & 4.64 & 2.27 & 0.97 & 2.95 & 0.00 & - \\
\hline & 2nd & & 4.66 & 2.29 & 1.00 & 3.00 & 0.00 & - \\
\hline & final & & 5.01 & 2.24 & 0.63 & 2.38 & 0.00 & - \\
\hline
\end{tabular}

\section{Revision Series}

Real Output

$$
e^{1} t, t+i
$$

Quarter

$0.25(.12)$

2.01

0.43

0.07(.63)

$\mathrm{e}_{\mathrm{t}, \mathrm{t}+\mathrm{i}}^{2}$

$0.20(.00)$

$\mathrm{e} 1^{2} \mathrm{t}, \mathrm{t}+\mathrm{i}$

$\mathrm{e}_{\mathrm{t}, \mathrm{t}+\mathrm{i}}^{1}$

Year

$0.12(.38)$

$\mathrm{e}_{\mathrm{t}, \mathrm{t}+\mathrm{i}}^{2}$

$0.06(.63)$

0.06(.04)

$\mathrm{e} 1^{2} \mathrm{t}, \mathrm{t}+\mathrm{i}$

Quarter

$0.45(.00)$

$0.35(.00)$

0.11(.05)

0.38(.00)

$0.35(.00)$

0.02(.14)
1.98

0.79

0.89

0.82

0.32

1.18

1.19

0.39

0.11

1.04

0.92

1.12

$-0.03$

$-0.73$

0.49

0.87

$-0.11$

0.61

0.61

$-0.29$

0.15

0.73
4.11

4.00

2.99

5.26

5.67

8.47

4.94

7.22

5.59

4.84

5.64

5.03

$$
\begin{array}{ll}
0.01 & (.13, .08, .09) \\
0.02 & (.27, .07, .06) \\
0.89 & (.13, .70, .17) \\
0.00 & (.00, .00, .00) \\
0.00 & (.00, .00, .00) \\
0.00 & (.56, .99, .98) \\
0.00 & (.93, .90, .34) \\
0.00 & (.89, .76, .13) \\
0.00 & (.16, .01, .00) \\
0.00 & (.00, .00, .00) \\
0.00 & (.00, .00, .00) \\
0.00 & (.26, .42, .21)
\end{array}
$$




\section{Table 2: CRR Regressions Using Raw Innovations}

First, for each year in the dataset, we estimate time-series regressions of each stock return on the macro news variables to obtain the (time-varying) risk factors. We use 60 quarters of past data in each annual regression. Second, at the end of each year in the data set, we estimate quarterly cross-sectional regressions of stock returns on the betas for the next four quarters, from which we obtain a time series of risk-premia. Third, from the timeseries of risk premia, we calculate the averages over time and standard errors and tstatistics. Panel A uses final release macro data and Panel B uses real-time macro data. The expectations of the macroeconomic innovations are assumed to be constant.

\section{A: Final Release Data}

\begin{tabular}{|c|c|c|c|c|c|}
\hline & Constant & Annual Output & Quarterly Output & $\underline{\text { GDP Deflator }}$ & Credit Premium \\
\hline Average Risk Premium & 1.954 & 1.818 & & -3.806 & 3.215 \\
\hline Standard Deviation & 1.351 & 1.618 & & 1.148 & 1.114 \\
\hline t-Statistic & 1.446 & 1.124 & & -3.314 & 2.885 \\
\hline Average Risk Premium & 0.994 & & 1.844 & -4.337 & 4.039 \\
\hline Standard Deviation & 1.510 & & 2.454 & 1.134 & 1.280 \\
\hline t-Statistic & 0.658 & & 0.751 & -3.824 & 3.155 \\
\hline Average Risk Premium & 2.376 & 2.022 & 2.961 & -3.992 & 2.756 \\
\hline Standard Deviation & 1.338 & 1.552 & 2.086 & 1.102 & 1.366 \\
\hline t-Statistic & 1.776 & 1.303 & 1.419 & -3.624 & 2.019 \\
\hline \multicolumn{6}{|l|}{ B: Real-Time Data } \\
\hline & $\underline{\text { Constant }}$ & $\underline{\text { Annual Output }}$ & Quarterly Output & $\underline{\text { GDP Deflator }}$ & $\underline{\text { Credit Premium }}$ \\
\hline Average Risk Premium & 2.952 & 2.345 & & -2.776 & 2.187 \\
\hline Standard Deviation & 1.291 & 1.336 & & 0.977 & 1.027 \\
\hline t-Statistic & 2.287 & 1.756 & & -2.841 & 2.129 \\
\hline Average Risk Premium & 2.360 & & 3.611 & -3.178 & 2.925 \\
\hline Standard Deviation & 1.249 & & 2.108 & 1.107 & 1.004 \\
\hline t-Statistic & 1.889 & & 1.713 & -2.872 & 2.914 \\
\hline Average Risk Premium & 4.035 & 1.328 & 2.619 & -1.990 & 1.052 \\
\hline Standard Deviation & 1.161 & 1.323 & 1.574 & 0.870 & 1.004 \\
\hline t-Statistic & 3.475 & 1.004 & 1.664 & -2.287 & 1.048 \\
\hline
\end{tabular}


Table 3: CRR Regressions Using Autoregressive Expecations

We form autoregressive expectations for the macro innovations as follows: In Panel A, final release data are regressed on final release data. In Panel B, final release data are regressed on real-time data, and in Panel C, real-time data are regressed on real-time data. Once the innovations are defined from these expectations then the analysis follows that in Table 2.

\section{A: Final Release Data Using Final Release Expectations}

$\underline{\text { Constant }}$ Annual Output Quarterly Output $\underline{\text { GDP Deflator }}$ Credit Premium

\begin{tabular}{|c|c|c|c|c|c|}
\hline Average Risk Premium & 4.157 & -0.550 & & -2.031 & 0.212 \\
\hline Standard Deviation & 1.194 & 1.680 & & 0.742 & 1.096 \\
\hline t-Statistic & 3.481 & -0.328 & & -2.738 & 0.194 \\
\hline Average Risk Premium & 2.843 & & -0.978 & -2.930 & 1.957 \\
\hline Standard Deviation & 1.409 & & 2.303 & 0.807 & 1.212 \\
\hline t-Statistic & 2.018 & & -0.425 & -3.633 & 1.616 \\
\hline Average Risk Premium & 3.676 & 0.321 & 0.070 & -2.282 & 0.991 \\
\hline Standard Deviation & 1.153 & 1.516 & 2.133 & 0.631 & 1.287 \\
\hline t-Statistic & 3.188 & 0.212 & 0.033 & -3.616 & 0.769 \\
\hline
\end{tabular}

\section{B: Final Release Data Using Real-Time Expectations}

\begin{tabular}{|c|c|c|c|c|c|}
\hline Average Risk Premium & 3.517 & -0.435 & & -0.427 & 1.170 \\
\hline Standard Deviation & 1.355 & 1.610 & & 0.859 & 1.240 \\
\hline t-Statistic & 2.596 & -0.271 & & -0.498 & 0.944 \\
\hline Average Risk Premium & 3.190 & & -0.108 & 0.486 & 2.001 \\
\hline Standard Deviation & 1.214 & & 2.092 & 0.871 & 1.093 \\
\hline t-Statistic & 2.629 & & -0.052 & 0.558 & 1.830 \\
\hline Average Risk Premium & 3.368 & 0.413 & 0.175 & -0.559 & 1.670 \\
\hline Standard Deviation & 1.202 & 1.673 & 1.978 & 0.700 & 1.250 \\
\hline t-Statistic & 2.802 & 0.247 & 0.088 & -0.798 & 1.337 \\
\hline
\end{tabular}

\section{C: Real-Time Data Using Real-Time Expectations}

$\underline{\text { Constant Annual Output Quarterly Output } \underline{\text { GDP Deflator }} \text { Credit Premium }}$

\begin{tabular}{|c|c|c|c|c|c|}
\hline Average Risk Premium & 4.679 & 0.094 & & -1.132 & -0.240 \\
\hline Standard Deviation & 1.331 & 1.658 & & 0.804 & 1.271 \\
\hline t-Statistic & 3.516 & 0.057 & & -1.408 & -0.188 \\
\hline Average Risk Premium & 4.088 & & 1.029 & -1.975 & 0.654 \\
\hline Standard Deviation & 1.187 & & 2.154 & 0.886 & 1.032 \\
\hline t-Statistic & 3.444 & & 0.478 & -2.228 & 0.633 \\
\hline Average Risk Premium & 4.716 & 0.066 & 0.641 & -0.902 & -0.360 \\
\hline Standard Deviation & 1.085 & 1.532 & 1.635 & 0.536 & 1.089 \\
\hline t-Statistic & 4.346 & 0.043 & 0.392 & -1.685 & -0.331 \\
\hline
\end{tabular}




\section{Liste des publications au CIRANO*}

Série Scientifique / Scientific Series (ISSN 1198-8177)

2001s-43 Fragmentation, Outsourcing and the Service Sector / Ngo Van Long, Ray

Riezman et Antoine Soubeyran

2001s-42 Nonlinear Features of Realized FX Volatility / John M. Maheu et Thomas H. McCurdy

2001s-41 Job Satisfaction and Quits: Theory and Evidence from the German

Socioeconomic Panel / Louis Lévy-Garboua, Claude Montmarquette et Véronique Simonnet

2001s-40 Logique et tests d'hypothèse : réflexions sur les problèmes mal posés en économétrie / Jean-Marie Dufour

2001s-39 Managing IT Outsourcing Risk: Lessons Learned / Benoit A. Aubert, Suzanne Rivard et Michel Patry

2001s-38 Organizational Design of R\&D Activities / Stefan Ambec et Michel Poitevin

2001s-37 Environmental Policy, Public Interest and Political Market / Georges A. Tanguay, Paul Lanoie et Jérôme Moreau

2001s-36 Wealth Distribution, Entrepreneurship and Intertemporal Trade / Sanjay Banerji et Ngo Van Long

2001s-35 Comparaison des politiques de rémunération en fonction des stratégies organisationnelles / Michel Tremblay et Denis Chênevert

2001s-34 Déterminants et efficacité des stratégies de rémunération : Une étude internationale des entreprises à forte intensité technologique / Michel Tremblay, Denis Chênevert et Bruno Sire

2001s-33 La multiplicité des ancres de carrière chez les ingénieurs québécois: impacts sur les cheminements et le succès de carrière / Yvon Martineau, Thierry Wils et Michel Tremblay

2001s-32 The Impact of Interface Quality on Trust in Web Retailers / Marie-Christine Roy, Olivier Dewit et Benoit A. Aubert

2001s-31 R\&D and Patents: Which Way Does the Causality Run? / Hans van Ophem, Erik Brouwer, Alfred Kleinknecht and Pierre Mohnen

2001s-30 Contracting under Ex Post Moral Hazard and Non-Commitment / M. Martin Boyer

2001s-29 Project Financing when the Principal Cannot Commit / M. Martin Boyer

2001s-28 Complementarities in Innovation Policy / Pierre Mohnen et Lars-Hendrick Röller

2001s-27 Bankruptcy Cost, Financial Structure and Technological Flexibility Choices / Marcel Boyer, Armel Jacques et Michel Moreaux

2001s-26 Inflation as a Strategic Response / M. Martin Boyer et Pierre Thomas Léger

* Consultez la liste complète des publications du CIRANO et les publications elles-mêmes sur notre site Internet : 